\title{
10. Pinning down Kaurna names: Linguistic issues arising in the development of the Kaurna Placenames Database
}

\author{
Rob Amery \\ University of Adelaide \\ Vincent (Jack) Kanya Buckskin \\ Kaurna Warra Pintyanthi \\ University of Adelaide
}

Kaurna people are in the process of reclaiming their identity and their language, a language that was considered to be 'extinct' by many or 'sleeping' by the people themselves (see Amery 2000a). Kaurna people have expressed the view at Kaurna Warra Pintyanthi (KWP) meetings that they wish to see Kaurna words spelt and pronounced correctly and are keen to see that Aboriginal placenames in use on the Adelaide Plains conform to the sound patterns of the language. Names that appear to be of Indigenous origin are being sifted through. Those that can be verified as Kaurna names are retained, others are discarded and some are translated into Kaurna or adapted into the Kaurna sound and spelling systems.

We are attempting to also pin down the meanings of Kaurna placenames. It can be shown (see Amery 2002) that some etymologies that have been put forward are fanciful and verifiably false. Others are highly questionable. In many cases we simply do not know. There are also difficulties in determining what a particular name relates to, or whether variants are simply spelling variations for the same word, or were in fact attempts to spell different though somewhat similar names. So pinning down the form depends on pinning down the meaning and vice-versa.

A set of principles for dealing with such uncertainty has been developed by KWP. We will give many examples where these principles can be applied and other examples where we are still at a loss as to how we should deal with the names in question.

Kaurna people are also reinstating some of the original names through DualNaming legislation with the help of the South Australian state government 
Geographical Names Unit. Other features, notably parks and wetlands, are being named with Kaurna names that relate in some way to the geographical features, local vegetation or indeed to commemorate Kaurna ancestors (see Amery and Williams 2002; Amery and Rigney 2006). In addition, since 1980 many organisations, programs, buildings, rooms and events etc are being given Kaurna names. This naming activity began slowly, but has increased exponentially over the last few decades.

The Kaurna community has been at the forefront of efforts by Aboriginal peoples in urban areas to reinstate and strengthen an identity, a people, a culture and a language. Similar efforts are also being made in Sydney (see Troy and Walsh, 2009), Melbourne, Perth, Canberra and other centres, sometimes drawing on the Kaurna experience for inspiration and support. When the naming of Adelaide city parks was first invoked there was some concern regarding the length of some Kaurna names and perceived pronunciation difficulties (see 'Unsayable Adelaide' letter to the editor, The Advertiser, Monday 10 February 1997), but also a very positive and encouraging letter in response ('All South Australians can feel proud', The Advertiser, Saturday 15 February 1997: 24). Reportage has been factual and neutral to positive. Since then there has been no further response. Adelaideans fully accept the Kaurna names.

\section{Introduction}

Kaurna is the language of the Adelaide Plains, a small tract of land in South Australia extending west of the Mount Lofty Ranges from Crystal Brook and Clare in the north to Cape Jervis south of Adelaide. Various wordlists were compiled by a range of observers. A number of these wordlists include placenames, notably Teichelmann and Schürmann (1840), Williams (1840), Piesse (1840) and Wyatt (1879). Others also recorded placenames. Snippets of information from various sources were collected by Norman B. Tindale who compiled a series of placenames card files, including one of Kaurna placenames (Tindale n.d.). Compilers of books on South Australian placenames, notably Cockburn (1990), Manning (1990) and Praite and Tolley (1970) also include odd pieces of information and it is often difficult or impossible to track down the source of specific snippets of information in these publications. Chester Schultz has been engaged over the past five years in the laborious task of sifting through archives and old records in an attempt to do just this - find wherever possible the earliest records in that small window when colonists heard the Kaurna names directly from the mouths of native speakers of Kaurna. See Schultz (2011, 2012) and earlier work (Schultz 1999). 


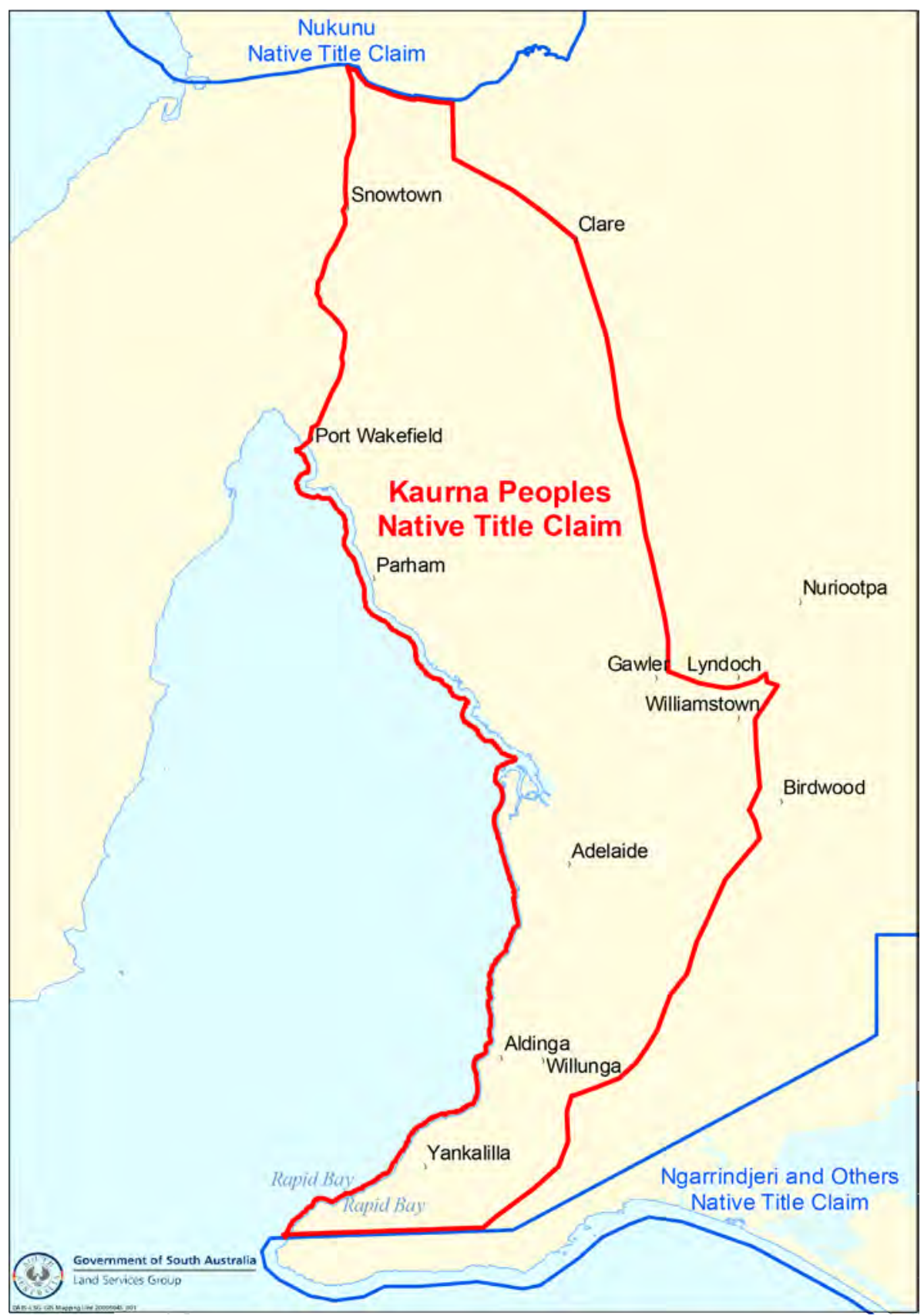

\section{Map 1: Kaurna Native Title Claim map.}

Source: Government of South Australia, Land Services Group. 
Kaurna is a language that is undergoing a renaissance. It was probably last spoken on a daily basis no later than the 1860s. Many, including Teichelmann (1857), who knew the Kaurna people well, have described it as 'dead' or 'extinct' (see Amery 2000a: 49 for further details), though Kaurna people themselves would prefer to think of it as a 'sleeping' language which is being 'woken up'. The Kaurna language is being re-learnt and re-introduced on the basis of the aforementioned written records.

Placenames are of increasing interest to members of the public. Accordingly, in 2006 the City of Onkaparinga initiated a project to display Kaurna names on Google Earth maps on the internet. This project is a collaborative work between the Geographical Names Unit (GNU) of South Australia, Kaurna Warra Pintyanthi (KWP) based at the University of Adelaide (see www.adelaide.edu. $\mathrm{au} / \mathrm{kwp}$ ), the Tappa Iri business centre and the four southern councils (City of Onkaparinga, City of Marion, City of Holdfast Bay and Yankalilla). The GNU provides geographic information system (GIS) information, assists in locating the names and makes its archives accessible. KWP makes judgements about the form (that is, morphology, spelling and pronunciation) and the meaning of the names. The City of Onkaparinga provided overall coordination and management of the project and a reference committee was established that drew all partners together. Beanstalk, a website developer, was contracted to build the webpages and facilitate importation of data from the database, whilst the database itself was developed by the GNU and KWP. Some information is displayed publicly, whilst other more technical, controversial or sensitive material is password-protected (for the use of Kaurna people, project partners and legitimate researchers). The webpages may be viewed at http://www.kaurnaplacenames.com.

Some of Schultz's research, which is included in Schultz (1999, 2011, 2012), and write-ups of additional names is posted on the KWP webpages. Much more will be posted in due course with links from the Kaurna Placenames website.

\section{Research questions}

Toponymy research concerns a number of different but inter-related parameters. These inter-relationships are heightened where researchers are trying to make sense of patchy historical documentation in the absence of native speakers, as Schultz (2011) discusses in some detail. This paper investigates placenames in terms of:

i) Form

a. What is the underlying phonemic representation? 
b. How should the name be represented in public?

ii) Morphology

a. Is the name composed of several morphemes (meaningful parts)? It may consist of one or more roots plus one or more suffixes.

iii) Meaning

a. Does the name have a meaning at all? It may not.

b. What are the different documented meanings?

c. What is the evidence/counter-evidence supporting or detracting from each of these meanings?

iv) Etymology

a. What is the language(s) of origin of the name?

b. How did the name come to be applied to the particular feature or location?

v) Referent or Location

a. What geographical or physical feature does the name apply to?

b. What is the extent of the reference? Is it a specific feature able to be identified with a pin on a map, is it a bounded area, is it a diffuse, unbounded feature, or does the name operate at several levels simultaneously?

c. What is the relationship between the original name and the current entity to which the name applies?

Because of imprecise early spelling, to identify the form we need to know the meaning. To identify the meaning we need precision in the recording of the form. To judge the plausibility of a given meaning we need to understand the limits of the recording of the form and the various possibilities for its underlying phonemic representation. To know which meaning is possible or plausible, we need to know about the location. Any information about the etymology or history of the name helps to complete the picture. Morphology assists greatly in identifying the source language(s) and in turn the form, meaning and etymology.

Whilst much of the research carried out at the direction of KWP concerns placenames that have been in use for time immemorial and/or have been documented in the historical literature, research is not limited to these. Placenaming is ongoing, and with successes in the revival of the Kaurna language, new Kaurna placenaming activity is taking place. This recent activity will be discussed in section 7 towards the end of the paper, including some uncertainties that have arisen in the process. 


\section{The form of Kaurna placenames and their representation}

\subsection{Underlying phonemic representation and pronunciation}

Pronunciation is being reconstructed through comparison of variant spellings employed by the same observer, different spellings of the same word employed by different observers and through comparison with related forms in neighbouring languages. We can be 100 per cent confident about the pronunciation of some words, but there is an element of guesswork with others. At times there is an exceedingly large dose of guesswork involved. For instance, there were most likely three contrasting r-sounds in Kaurna. Not surprisingly, most who recorded Kaurna placenames made no effort to distinguish between them. Even Teichelmann and Schürmann (1840), henceforth T\&S, who were far better at recording Kaurna words than most, did not adequately distinguish between them. They recorded the name for the River Torrens as Karrauwirraparri (RS Karrawirra Pari $)^{1}$ with three lots of double rr's. We know from comparison with other languages that the first two sets are rolled or trilled rr's whilst the rr in T\&S parri is a glide as in Australian English. T\&S spelling is of little help in deciding the pronunciation of the r's or the $t, 1$ and $n$ sounds, which may be interdental (tongue between the teeth), alveolar (as in English) or retroflex (tongue tip turned back).

\subsection{Orthography issues}

\subsubsection{T\&S spellings}

The German missionaries compiled by far the most comprehensive records of the language and their spellings, despite some shortcomings, are reasonably consistent and systematic. For the first 20 years of Kaurna language revival efforts since the early 1990s, we employed T\&S spellings and when words from other sources were co-opted they were re-spelt to fit in with T\&S conventions (see Amery 2003). Most importantly T\&S spellings afforded the revived language an authenticity as the words used could be more readily traced back to the original source material.

\footnotetext{
1 Throughout this paper, by necessity, a mixture of different spelling conventions are employed. Placenames generally appear in regular font as they appear on the map or in published sources. At times these names also appear as they would be spelt in the Revised Spelling system adopted in 2010 in which case they are preceded by the letters RS. Placenames on the Kaurna Placenames website also appear in a form adapted to T\&S spelling conventions which were sanctioned by the Kaurna language revival movement prior to 2010, though these will soon appear in Revised Spelling. Regular Kaurna words and phrases appear in italics in Revised Spelling.
} 


\subsubsection{Revised Kaurna spellings (2010)}

In 2010 at the urging of Buckskin, who was by that time the main teacher of the Kaurna language across multiple programs, the Kaurna language movement adopted a phonemically inspired orthography which more closely represented the distinctive sounds of Kaurna. The uncertainties in knowing how to pronounce many Kaurna words was confusing and disconcerting for students, and rather than having to frequently check with Amery, Buckskin wanted to pin down the pronunciations once and for all. This could be done once firm decisions were made about the underlying phonemic representation of each and every word based on extensive language-internal and comparative research. Orthography issues were discussed at a number of KWP meetings and several versions of the new spelling system were trialled within a PowerPoint presentation that had been prepared for the Kaurna Learner's Guide (Amery and Simpson 2013). In this way KWP members and teachers and community members at Kaurna Plains School could see what the new spelling conventions would look like. Where there is absolutely no evidence to indicate vowel length, short vowels are employed, unless there are other considerations such as to avoid a linguistic taboo. For example, Buckskin argued for the spelling of T\&S nepo 'neighbour; friend' as niipu, though there is no evidence to suggest a long vowel, in order to avoid association with English 'nipple'. Likewise, if there is no evidence to suggest an interdental or retroflex consonant, then usually alveolars $(t, n$ and $\mathrm{l}$ as in English) are employed, unless there is a particular need to differentiate between two similar words. The glide $r$ as in Australian English is usually the default r-sound, unless there is evidence to the contrary.

Buckskin immediately began to use the revised Kaurna spellings in 2010 in his evening Kaurna language classes with adult students and in his day classes with adolescent students at Salisbury High School. He saw how easily students learnt the new spelling system which gave certainty and precision as to how Kaurna words should be written and pronounced. At the same time, Amery began to use revised spelling in the script of radio shows in preparation in 2010, and saw how easily participants were able to adapt to the new system, despite their previous considerable familiarity with T\&S spellings. The revised spelling system was explained in depth and taught throughout 2012 and early 2013 within the TAFE Certificate III course 'Learning an Endangered Aboriginal Language (Kaurna)' where all students responded very positively. All who have actually used the revised spelling system have found it easy to understand and apply.

\subsubsection{Spelling of Kaurna placenames}

The spelling of many Kaurna placenames in common use that appear in the street directory or on road maps bears little relationship to the original word. Examples 
such as Aldinga (probably /ngaltingka/), Onkaparinga (/ngangkiparingka/), Myponga (/maitpangka/ or /matypangka/) and Patawolonga (probably /pathawilyangka/) demonstrate this.

T\&S spellings were promoted up-front on the Google Earth maps on the placenames website. That was the spelling system in use by the Kaurna language movement at the time of establishment of the placenames project. In the database underpinning the website, all known spellings of the names and their sources are recorded and an attempt is being made to reconstruct the original forms. This is done using the analytic spelling system adopted by Simpson and Hercus (2004: 180) which uses lowercase letters when we are certain of the underlying phoneme and uppercase letters when we cannot tell its value with any degree of confidence. So for example in /ngALTingka/ Aldinga, there are three sources of uncertainty. The first vowel A could be a long aa [a] as in 'Bart' or a short a $[\Lambda]$ as in 'but'. The L and T could be either interdental /lhth/ with the tongue between the teeth, alveolar /lt/ as in English 'belt', or retroflex/rlrt/ with the tongue tip curled back. In both the T\&S spellings used up until 2010 and the revised spelling system, Aldinga will be rendered Ngaltingga.

The Kaurna name for McLaren Vale, spelt variously as Doringo, Taringa, Tarranga, Tu-run-ga, Dooronga, Doo-ronga, Daringa, Taranga, Tarangk, is even worse. ${ }^{2}$ We can represent it as /thVRVngka/ where there are three sources of uncertainty. We know that a t-sound at the beginning of a word is always interdental, so we can confidently write /th/. However, we are not sure whether the vowel in the first syllable is $/ \mathrm{a} /$ or $/ \mathrm{u} /$ or whether it is short or long. The $\mathrm{r}$-sound could be either a rolled $/ \mathrm{rr} /=[\mathrm{r}]$, tapped $/ \mathrm{rd} /=[\mathrm{r}]$ or glided $/ \mathrm{r} /=[\mathrm{I}]$. There is so much discrepancy between the sources that we are not certain what kind of vowel is in the second syllable. It is unclear whether it is $[\mathrm{I}]$ as in 'bit', $[\Lambda]$ as in 'but' or $[\Phi]$ as in 'put'. Given so much uncertainty, we simply indicate that there is some kind of vowel present. This spelling is ideal for analytical purposes because it signals immediately the areas of certainty and uncertainty, but it is obviously less than ideal for use with the public. But any version of this particular name for public display is something of a blind guess.

Knowledge of Kaurna phonotactics helps reduce some of the uncertainty. Only certain sounds ( $\mathrm{p}, \mathrm{th}, \mathrm{k}, \mathrm{m}, \mathrm{nh}, \mathrm{ng}, \mathrm{w}, \mathrm{y})$ are allowable at the beginning of words and every word must end with a vowel. Because Kaurna words never commence with alveolar or retroflex consonants, we decided to write the initial interdental /th/ and / $\mathrm{nh} /$ sounds as $\mathrm{t}$ and $\mathrm{n}$ respectively, though they should actually be

2 The wide range of variant spellings raise the possibility that there may even have been two similar names for two different localities in close proximity within the McLaren Vale area. 
pronounced with the tongue between the teeth. Long vowels are only permitted in the first syllable. Initial consonant clusters, with the possible exception of thR, are not permitted. Syllables in Kaurna are either CV, CVC or rarely CVCC.

\subsubsection{Revised Kaurna spelling and placenames}

Placenames are undoubtedly the most difficult area of the language in which to implement spelling reforms and especially so in the case of Kaurna. This is because so many Kaurna placenames have no known meaning and many were recorded by unknown individuals or as one-off instances. So there is no way of checking author spelling preferences. It is really only in the case of the four wordlists mentioned earlier, that is Teichelmann and Schürmann (1840), Williams (1840), Piesse (1840) and Wyatt (1879), that any determination can be made as to the kinds of conventions adhered to by the recorder. With questionable spellings and in the absence of a trusted meaning there are few cues by which we can relate many placenames to other recorded words. Kaurna placenames researchers, Schultz and Amery, look for plausible endings or suffixes and plausible meanings (see below), but many attempts to arrive at phonemic spellings for Kaurna placenames are really clutching at straws or making stabs in the dark and it is important that this is recognised.

Many Kaurna placenames of course are in use in the public domain on maps, in street directories and in other publications. They also appear on signage. Kaurna placenames are the most visible aspect of the living Kaurna culture in the landscape on the Adelaide Plains. The Kaurna language has no visibility in the commercial world, such as on billboards or in advertisements etc. To date there is no strong movement for the replacement of existing names or signage as with, for instance, the replacement of Peking with Beijing or Bombay with Mumbai. Adelaide City Council has recently been made aware of the revised spellings for Kaurna names for the parks and squares. In the event that signage is replaced, revised spellings may then be adopted. Indeed, new requests for names of parks, streets, trails, bridges or other named places which are put to KWP since 2011 are being spelt with revised Kaurna spellings. This results in a number of different spelling conventions being used concurrently, which is far from ideal.

In due course, the public will be made aware of the revised spellings alongside of spellings in current use. As at the time of writing the Kaurna Placenames website displays the T\&S spelling alongside the heading "Kaurna Name", whereas the name in public usage appears alongside "Common Name". For example:

Kaurna Name: Wommamukurta

Common Name: Mount Barker

Additional Notes: Also recorded as Womma Mukarta, Yaktanga. 
Spelling issues for the Kaurna Placenames website were discussed at the KWP meeting on 15 November 2012. The meeting resolved to create an additional field "Old Spelling" and to migrate the content of the current "Kaurna Name" category to "Old Spelling" whilst the Revised Spelling form will be inserted in the Kaurna Name field. Thus, the entry above will appear as:

Kaurna Name: Wamamukurta

Common Name: Mount Barker

Old Spelling: Wommamukurta

Additional Notes: Also recorded as Womma Mukarta, Yaktanga.

The Common Name may in fact be a Kaurna name and in the case of names presently approved by KWP it will be exactly the same as the Kaurna name as in the case of the Defence SA 23 hectare reserve named Kardi Yarta 'emu ground' (KWP Minutes, 26 October 2011). Even for some long-standing names such as Yultiwirra, the Old Spelling may be identical to the Revised Spelling, so that it is possible that all three fields may be identical.

\subsection{The shape (morphology) of Kaurna words and placenames}

Morphology is the intersection between form and meaning. Morphology analyses words into their smallest meaningful parts (morphemes) and is sometimes an essential step in determining possible meanings of placenames.

Most Kaurna words consist of a single two syllable morpheme. Quite a few consist of a three-syllable morpheme. Less commonly they might be a single syllable with a long vowel. Like other Australian languages, Kaurna uses case suffixes instead of prepositions and for a number of other functions, so Kaurna nouns may take quite a range of endings which sometimes occur in documented placenames.

Many Kaurna placenames appear with a location suffix -ngga (/-ngka/) on twosyllable roots (e.g. Nurlungga, Waitpingga, Maitpangga and Wilangga) or -illa (/-ila/) on three-syllable roots (e.g. Kawantilla, Yarnkalyilla and Kangkarrilla). A special concession was adopted within the revised spelling system introduced in late 2010 in relation to this locative suffix on placenames. The T\&S spellings, -ngga and -illa, are retained on placenames (spelt with initial capitalisation), whilst -ngka and -ila are employed on common nouns.

As a result of this spelling convention, nurlungka (/nhurlungka/) means 'at the corner' but Nurlungga with exactly the same pronunciation but slightly different spelling means 'at Nurlu' (or 'at Nurlo' in its original form). The name 
Nurlu 'corner; curvature' refers to 'the Horseshoe' (the bend on the Onkaparinga River at Old Noarlunga). We could use other case suffixes in other contexts such as nurlunangku 'from the corner' vs Nurlunangku 'from Nurlu (Old Noarlunga)', nurlulityangka 'in the vicinity of the corner' vs Nurlulityangga 'in the vicinity of Nurlu (Old Noarlunga)', nurlu-ana 'to the corner' vs Nurlu-ana 'to Nurlu', nurlu-arra 'alongside Nurlu' vs Nurlu-arra 'via Nurlu'.

Often placenames have been recorded both with and without the location suffix as in Tarndanya vs Tarndanyangga; ${ }^{3}$ Warriparri vs Warriparringga and Pattawilya vs Pattawilyangga. How should the name appear on the map? Should these pairs of names be regarded as one or two names? The foregoing pairs have been listed as separate names because they now refer to distinct locations or entities. Tarndanya refers to the city of Adelaide south of the Torrens as specified in T\&S (1840: 75) whilst Tarndanyangga has been used in dual-naming Victoria Square in the heart of the city. Warriparri refers to the Sturt River, whilst Warriparringga refers to the specific Warriparinga site formerly known as Laffers Triangle where the Living Kaurna Cultural Centre is located. Pattawilya refers to Glenelg, whilst Pattawilyangga refers to the Patawalonga waterway. However, in their original form and reference, these names referred to one and the same place, the place itself vs being at that place.

Kaurna also has a dual suffix -rla or -dla which contrasts with the plural suffix -rna. The dual suffix appears in Yuridla 'ear-two' and Pikudla 'eyebrow-two'. In the neighbouring Nukunu language, the dual suffix is -pila. Thus Yurrebilla is probably just another form of the name Yuridla meaning 'two ears' referring to the two peaks Mt Lofty and Mt Bonython. It is known that at the time of first contact there were several dialects of Kaurna. The fact that the neighbouring closely-related language to the north (Nukunu) uses -pila leads us to speculate that it could also be the form of the dual suffix in one of the more northerly Kaurna dialects. Assuming Yuridla equals Yurrebilla, how should we treat them today? Yuridla these days refers to the nearby town of Uraidla, whilst Yurrebilla refers to a walking trail at Mt Lofty. It is probably best to simply note that they most likely mean the same thing.

Often placenames consist of compounds of two, and sometimes three Kaurna words, perhaps with suffixes added as in Yultiwirra (yulti 'stringybark' + wirra 'forest'), Ngangkiparringga (ngangki 'woman' + pari 'river' + -ngga 'LOC') and Karrauwirraparri (karra 'redgum' + wirra 'forest' + pari 'river'). Name elements like pari 'creek; river', wirra 'forest', yarta 'soil; ground; land', wama 'plain'

3 Tarntanyangga looks like it breaks the two-syllable rule governing the -ngga suffix. However, Tarntanya is a reduced compound, derived from tarnta 'male red kangaroo' and kanya 'rock' as evidenced by versions of the name, Dundagunya and Dharnda anya recorded from Ivaritji by The Advertiser and Daisy Bates respectively. See Gara (1990: 90, 93) and Amery (2002: 177). 
and wardli 'house; home' often appear as the second root in these compounds. Kanya 'rock', mukurta 'hill', wilya 'foliage', karla 'firewood', yarlu 'sea', warti 'tail', warta 'behind' are also known to occur in this slot.

Compounding is also seen in the property name Yankaponga, clearly a combination of Yankalilla and Myponga. Yankaponga is not a traditional Kaurna name but has been formed by the owners by combining two neighbouring traditional Kaurna names in the vicinity.

\section{Pinning down the meanings}

The meaning of some Kaurna placenames, such as Yultiwirra 'stringybark forest' or Karrawirrapari 'redgum forest river', is readily apparent, whilst for some names no meaning is given at all, nor is one readily apparent. Documented 'meanings' are found for many placenames, however, more often than not, the meaning is a source of much conjecture.

\subsection{Falsifiable or questionable meanings}

Whilst a wide range of meanings can be assembled for many placenames from published and archival sources, some of these are clearly falsifiable and others are highly questionable (see Amery 2002). An example will serve to illustrate the problem:

\subsubsection{Maitpangga - Myponga}

T\&S list this name Maitpa - ngga 'Matpunga Plain', but do not list maitpa in their vocabulary. Wyatt (1879: 23) spells it Maippunga again without definition. According to the State Gazetteer Myponga is an Aboriginal name meaning vegetable food place. Manning (1990: 218) says "according to H.C. Talbot it is derived from miappunga - 'divorced wife" " and "in a poem entitled 'Aboriginal Nomenclature - By a Native' which appeared in the Register on 11 October 1893, says it means 'high cliffs by the sea"". Cockburn (1990: 155) says "Myponga is corrupted from maipunga, meaning 'locality of high cliffs'. Another assertion that it is an Aboriginal term for 'divorced wife' may be discarded." Tindale in his Kaurna Placenames card file says:

Maitpangga $=[$ mai $]+[$ pa $]+[-n g g a]$. Pa is apparently a contraction of paru, namely animal food. Probably name applies to much of the length of the creek from Section 735 to beyond 740. Several versions of the name exist, the earliest being Teichlemann \& Schurmann as Maitpa and 
Maitpangga. Best interpretation of the name is probably vegetable food place from [mai] and [pangkara] a term applied to swamps \& lagoons.

Other versions and spellings exist (Tindale n.d.)

Now pangkarra means 'territory' whilst pangka means 'lake', so for starters Tindale has confused these two words. The ending -ngga is simply the locative suffix seen in numerous other Kaurna placenames. Tindale's assertion that Maitpangga is derived from mai 'vegetable food' + pangkara [or pangka] 'swamps and lagoons' or paru 'meat' are clearly fanciful. None of these account for the t. Our guess is that maitpa had no known meaning in the 1840s. It was simply a name. Otherwise T\&S and Wyatt would have most likely recorded it. We observed previously that most Kaurna words were bisyllabic. Maitpa is a single morpheme. It simply cannot be divided into mai + -tpa. It would be like trying to split English 'under' into the prefix un- + der. Of course der has no meaning. Neither has tpa in Kaurna. The tp cluster occurs frequently in Kaurna and is a distinctive marker of the Miru subgroup of languages to which Kaurna belongs.

\subsection{Ascribing meaning to placenames}

What about cases where no meaning is given in the source material? Two examples are given below to illustrate the problem.

\subsubsection{Callawonga}

No meaning was ever given to Callawonga as far as I know, yet Callawonga looks like it could be karla 'fire' + wanga 'grave' or wangka 'west' or wangka 'speak'. These names are plausible, especially when we take into consideration the Kaurna cultural practice of lighting a fire on the grave (Adams 1902: 9 quoted in Amery and A. Rigney 2006: 38). And if the wind can speak, for warri wanggandi (RS warri wangkanthi) 'the wind blows' was recorded (T\&S 1840: 54) it is likely that garla wanggandi (RS karla wangkanthi) 'the fire speaks/crackles' is also acceptable. There are at least three plausible alternatives here and they could all be wrong.

\subsubsection{Kanyanyapilla}

Similarly for Kanyanyapilla. Is this word formed from kanya + REDUP + -pila 'DUAL' meaning something like 'two lots of rocks'? It also looks like kanya 'rock' + REDUP + yapa 'hole' + -illa (T\&S kanyappa 'earth oven'). However, the addition of -illa in this situation would disobey the phonotactic rule of applying -illa to a three-syllable root. Kanyanya itself was recorded as 'crowd, multitude, heap' and pilla 'eagle'. So Kanyanyapilla looks like it might mean 'a multitude of 
eagles' or is it kanyanya 'multitude' + -pila 'DUAL' (ie 'two heaps')? Again there seem to be a multitude of ways of breaking this word up to make some sort of sense, but what basis do we have for doing so?

These examples were discussed in the KWP in April 2007. The meeting resolved that it is not wise to speculate wildly in cases like these. We do not want to fall into the same trap that Tindale appears to have done. Where we do not know what the meaning is, we say we do not know.

\section{Etymology}

Etymology concerns the origins and development of words and their meanings. In most instances, there is no documented etymology of historical Kaurna names, though we are making efforts to clearly document the etymology of current Kaurna naming activity, discussed later in section 7. Even in the absence of a documented etymology, at times the origins of a name are quite clear. At other times, they are the subject of conjecture as some of the following examples illustrate.

\subsection{Combinations of Kaurna and English}

In the same way that Yankaponga has combined two Kaurna placenames (discussed in section 3.3), nearby Ourponga, a property on Sampson Rd Myponga Beach, has combined English 'our' with the Kaurna element -ponga, and is obviously a play on words in response to the re-analysis of the Kaurna name Myponga (= my + ponga) in English with 'my' from English. ${ }^{4}$ Of course in Kaurna Myponga is analysed as maitpa $+-n g g a$ and the morpheme maitpa (meaning unknown) cannot be broken down further.

Similarly, a number of better established names on the map also combine Kaurna and English elements. Such names include Warradale, Glenunga, Parafield and Tappa Pass in the Barossa (which was formerly known as German Pass but was changed to Tappa Pass during World War I and has remained so ever since).

In developing the Kaurna placenames database KWP decided to translate these names fully into Kaurna. So Warradale became Warriwaltu (RS Warriwarltu) in the knowledge that the Warra- relates to Warriparri (RS Warripari) 'Sturt River' derived from warri 'wind' + pari 'river'. Dale is the term used in northern England for 'valley', thus translated into Kaurna as warltu 'valley'. Similarly

4 Similar play on words is seen in Nash's (2011: 120-129) study of roof names on Norfolk Island, sometimes combining Norf'k and English elements. 
glen is a Scottish term also meaning 'valley'. Thus Glenunga is rendered Waltungga (RS Warltungga). Para was an early corruption of pari 'river'. So Parafield became Parriyerta 'river-ground' (RS Pariyarta).

\subsection{Names recorded by Tindale and the Berndts from non-Kaurna sources}

Norman Tindale and Ronald and Catherine Berndt worked with a number of Aboriginal people from the lower Fleurieu and lower Murray regions who had some knowledge of the Adelaide Plains and associated Dreaming narratives, notably the Tjilbruke story. Some of these names are obviously Kaurna in appearance, whilst others break all the rules. Ruwarung, for instance, begins with an $r$ and ends with a consonant. No Kaurna words recorded by Teichelmann and Schürmann (1840), Wyatt (1879), Williams (1840), Piesse (1840), Robinson (ca 1837), Gaimard (1833), Koeler $(1842)^{5}$ etc. commence with $\mathrm{r}$ or l. Many names that Tindale and the Berndts recorded in this area, such as Patawiljayk, Witawatank, Tulukudank etc., end with the Ngarrindjeri location ending $-n g k$ (or $-n k$ ). This suffix is equivalent to Kaurna -ngga/-ngka/ (often written in historical documents and appears on maps as -nga as in Willunga, Aldinga, Waitpinga, Onkaparinga etc.).

Some of these Ngarrindjeri-looking names are clearly originally Kaurna names but have been assimilated into Ngarrindjeri. This is not surprising, as they were recorded from Ngarrindjeri speakers. Patawiljayk (Glenelg) as recorded by Tindale or Patawilyandjalang as recorded by Berndt and Berndt (1993) is a clear example of this. This same name was recorded as Pattawilya by T\&S (1840) and appears on the map as Patawalonga (with the -ngga location ending). This name is analysable in Kaurna as patha 'a species of gum tree' (possibly swamp gum) + wilya 'foliage'.

If this happens with a well-known, high-profile Kaurna name, then it is likely also that some of the other Ngarrindjeri-looking names not recorded in other Kaurna sources are also originally Kaurna names that were assimilated into Ngarrindjeri by Milerum and Karlowan (who were informants for Tindale and the Berndts).

A set of options for dealing with Ngarrindjeri-looking names were put to the KWP meeting in April 2007. These were:

1. Ignore. For example, Ngutarangk (Rapid Bay) was recorded by Meyer (1843) as the name for Rapid Bay. Meyer was documenting Ramindjeri. Others

5 Koeler does include lubera 'woman' in his word list, but this is known to be a word in common use in South Australian Pidgin English at the time. It originates from Tasmanian languages. 
recorded Yattagolunga/Yatagolanga (RS Yartakurlangga) as the Kaurna name for Rapid Bay. Thus it is best to ignore Ngutarangk.

2. Translate into Kaurna. For example, Paldarinawar = paldari 'salt' $+-n a$ ?? + -war 'LOC' in Ngarrindjeri. This might be translated into Kaurna as kityangga 'salt place' or kityakauwingga 'salty water place'.

3. Assimilate into Kaurna phonotactics. Accordingly Tulukudangk has been rendered Tulukudangga, Ka'raildung as Karildilla and Ruwarung as Wirruwarrungga ${ }^{6}$ (see Amery 2000b: 38).

4. Keep as it is even though it disobeys Kaurna phonotactic rules. Dulil was proposed as a possible example of this.

5. Accept some intermediate form. For example Rekarnung might be rewritten as Rikarnungga with a transparently Kaurna suffix, even though it commences with $\mathrm{r}$.

The Minutes record that:

The meeting resolved to accept the first three options only (ie 1. Ignore, 2. Translate into Kaurna, 3. Assimilate into Kaurna phonotactics). The meeting totally rejected the option of accepting a name of Ngarrindjeri appearance as a Kaurna name. An intermediate form (such as Tjilbruke) might be accepted occasionally with reluctance if there were compelling reasons. (KWP Minutes, April 2007).

\subsection{Placename or descriptive?}

There are a number of instances where the recorded 'name' may not be a true toponym, but rather a descriptive that was misunderstood as a placename. Yatala (RS Yartala), now referring to the prison but earlier in 1846 to the Hundred of Yatala and Section 422 in the Hundred of Yatala subdivided by Osmond Gilles circa 1848 (Manning 1990: 351) and a host of other names is another particularly good case in point. T\&S list yertalla 'water running by the side of a river; inundation; cascade'.

'Yatala' was thought at first to be the name of the Torrens River (Stephens 1839: 105). Later a variant 'Yerta-illa' was remembered by settlers as being a name for 'land on the north bank of the Torrens'; and also 'Yatala' as the name for a tract of land 'extending from Port Adelaide to Teatree Gully'. The latter was no doubt the reason for the name given to the Hundred of Yatala in 1846, and the

6 The Kaurna referred to Encounter Bay as Wirramu or Wirramula, though it was known to the Ramindjeri as Ramu or Ramong. As Kaurna words do not commence with $r$ it appears that an extra syllable has been added to the front of the Ramindjeri word and the Kaurna location suffix added to the resultant three syllable word. By analogy, Wirruwarrungga was formed from Ruwarung. 
old suburb of Yatala near today's Rosewater. All of these areas were subject to inundation from either creek flooding or tides. According to Manning (1990: 351) the Dry Creek area became flooded when water flowed from the hills. The weight of evidence suggests that originally Yartala was simply a descriptive which was co-opted by the colonists in their endeavours to name things including a government schooner and subsequently Yatala Shoal and Yatala Reef as well as a suburb Yatala Vale (gazetted in 1978).

Hercus (2002: 67-68) discusses examples from Victoria such as yaluk meaning 'creek' in some western Victorian languages which is recorded as the name of watercourses at quite different locations. This suggests that a descriptive was probably misunderstood to be a name, as has also probably occurred in the case of Yartala in Adelaide.

Parnka is listed by T\&S as Lake Alexandrina in their "Names of Places and Rivers" section (T\&S 1840: 75). Is Parnka really the toponym 'Lake Alexandrina' or is it simply the word for 'lake'? Certainly Schürmann and Teichelmann believed that it was both placename and descriptive as they list pangka in the vocabulary section (T\&S 1840: 36) as 'lake; lagoon; n.pr. Lake Alexandrina'. Hercus (2002) discusses a number of cases like these. In Paakantyi, the Darling River is known simply as Paaka '(The) River' whilst the Diamantina/Warburton is known as Karla '(The) Creek' in Wangkanguru, being the only significant rivers and creeks in their respective areas.

\subsection{Relative location or placename?}

Hercus and Simpson (2002: 17-18) discuss the names Cowandilla, now an inner suburb of Adelaide and Patpangga. But kawantila means 'in the north' and patpangka 'in the south'. Were these originally true placenames or descriptors of relative location from the speaker at the time of inquiry or a descriptor of relative location from some unspecified feature? Schultz (2011: 26-27) does not regard patpangka to be a placename but rather an area descriptor of the country from Cape Jervis north to at least Carrickalinga and perhaps Myponga Beach or up to Sellick's Hill. ${ }^{7}$ However, Wyatt (1879) recorded Patpungga (= Patpangga) for Rapid Bay though he probably never actually visited the place himself, and as we saw earlier, Rapid Bay has its own Kaurna name, Yartakurlangga.

7 Protector Matthew Moorhouse recorded "Patpunga, or those inhabiting the southern coast from Mt Terrible to Rapid Bay" in his Second Quarterly Report, 14 January 1840. 


\section{Pinning down locations}

No Kaurna placename in use today refers to precisely the same entity that it once referred to when the language was still strong and vibrant. Piltawodli (RS Pirltawardli) in the late 1830s and 1840s was a 14-acre selection of land on the north bank of the River Torrens adjacent to the present day Torrens Weir which served as the 'Native Location'. Its boundary is known with reasonable accuracy. However, it is unknown as to what Piltawodli referred to in the minds of Kaurna people before it became the 'Native Location'. Was it a specific site? Or was it even a post-contact name referring to the huts constructed there? Today it refers to a much larger expanse of parkland known otherwise as Park 01. Even the names of rivers probably only applied to certain tracts of those watercourses. For instance, Ngangkiparri 'women's river' probably applied to a tract of the Onkaparinga in the Old Noarlunga area. It is known that women would seek refuge in the ravines to the immediate east of South $\mathrm{Rd}$ and the area was apparently a women's sacred place. It is most unlikely that the name Ngangkiparri would have been applied to the Onkaparinga near Hahndorf in the Adelaide Hills, though we do not know the Indigenous names for upper reaches of this river.

The original location of some names, such as Yurridla (RS Yuridla), is known with some certainty because they applied to particular known features. One early source (Piesse 1840) is particularly useful in determining the precise location of a handful of names because, being a surveyor, he supplied section and district numbers for these names in the Willunga-McLaren Vale area. Unfortunately, most sources are vague as to the whereabouts of the placenames provided. Teichelmann (1857) includes a Kaurna placename Nortumbo, in an example sentence:

wanti-dlo na nurntidlo padni? nguntarluntya Nortumbotarra

where.to-up 2PL away-up went there-up-ALL Nortumbo-PERL

'whither are you gone away? thither in the direction of Nortumbo' (TMs nguntarlo)

Teichelmann fails to locate the name, and as this name was not recorded by any other observer, it could be anywhere on Kaurna country or even beyond. Tindale, in working with historical sources, is known to have mis-located at least some names.

Chester Schultz has undertaken intensive excursions throughout the region armed with descriptions from the range of historical sources available. We need to attempt to imagine the country as it was prior to changes arising 
from clearing the land and the impact of agriculture, roads and urbanisation. Recorded names most likely refer to springs, water sources and campsites, some of which have been identified.

\section{Current naming activity}

Largely as a result of the linguistic and cultural renaissance in Adelaide since 1989 (see Amery 2000a), there has been renewed interest in Indigenous names and various initiatives have been implemented to reinstate, recognise and introduce Kaurna names. Dual naming provides a means whereby original Kaurna names might be recognised for features known by other names, but there are also opportunities to apply new names to previously un-named features.

Since its establishment in 2002, Kaurna Warra Pintyanthi (KWP) has served as a forum to discuss hundreds of requests for Kaurna names and translations at its regular monthly meetings. The Geographical Names Unit and a range of local government entities regularly consult KWP in addition to other bodies.

At first thought one may think that current naming activity should be straightforward in terms of knowing what the form, meaning, etymology and location are for any given new name. As it turns out, many of the issues raised within this paper come into play in several recent new names that have been recognised or proposed in the last few years within the area of study. Several case studies will serve to illustrate.

\subsection{Re-instating original Kaurna names}

Warriparinga is probably the first original Kaurna name to be re-instated. Its use in recent times dates back to 1992. See Amery and Williams (2002: 259-262) for a detailed discussion of Warriparinga. Several original Kaurna names, Piltawodli (RS Pirltawardli), Tambawodli (RS Tampawardli), Kainka Wirra, have been reinstated through the Adelaide City Council Kaurna placenaming initiative. These and other initiatives are discussed in Amery and Williams (2002).

\subsection{Dual-naming}

Dual naming enables the original name of a geographical feature to be recognised alongside of another existing name. Hodges (2007: 393-395) provides a comprehensive overview of dual naming within Australia. Ayers Rock/Uluru (now Uluru/Ayers Rock) and Mount Olga/Kata Tjuta was the first instance of official dual naming within Australia in 1993. In 1993 the South Australian parliament accepted a set of guidelines allowing for the recognition of 
Aboriginal names. In 1999 dual naming was formalised in an amendment to the Geographical Names Act 1991. Karrawirra Parri (Torrens River) (RS Karrawirra Pari) was the first such Kaurna name to be officially recognised as a dual name in November 2001.

Dual naming only applies to natural features thus its scope of application is restricted. For instance, Kaurna names are known for several entities, including Adelaide = Tandanya (RS Tarntanya) and Port Adelaide $=$ Yertabulti (RS Yartapuulti). But these Kaurna names cannot be recognised as dual names. Any entity that has a postcode lies outside the scope of the dual naming legislation. The official recognition of the Kaurna names for these entities would require a name change.

\subsubsection{Creek names}

Dual naming only applies to original names. In 2008 The City of Campbelltown and City of Norwood, Payneham and St Peters approached KWP about the naming of 1st to 5th creeks. A series of Kaurna names, Palti Parri 'ceremony creek', Wirrabulto Parri 'remnants of a forest creek', Narni Parri 'goatsucker (nocturnal bird) creek' Morialta Parri 'eastern cascade creek' and Ngaltaitya Parri 'yabby creek' respectively were proposed based on resident fauna and flora and historical information (KWP Minutes, August 2008). It turned out that the creeks already had gazetted European names, Greenhill Rivulet $=$ First Creek, Hallett Rivulet $=$ Second Creek, Todd Rivulet $=$ Third Creek, Anstey Rivulet $=$ Fourth Creek, Ormsby Rivulet $=$ Fifth Creek, having been named by Colonel Light in the early days of the colony, though these names are not actually in use. Only Morialta Parri $=4$ th Creek was accepted for recognition under dual naming legislation as the other names were newly applied names with no historical precedence. The remainder would have to be put forward as name changes if Campbelltown, Norwood, Paynhem and St Peters Councils wished to proceed with recognising the other Kaurna names.

\subsubsection{Brian Nadilo - Ngutinilla Reserve ${ }^{8}$}

A name was sought by the City of Holdfast Bay for the new reserve established following the demolition of Magic Mountain at Glenelg. KWP suggested Ngutinilla 'Ngutinai's place' in recognition of Ngutinai (spelt Ootinai in the original sources), a Kaurna man who was invited aboard ship (possibly the Buffalo) during the first weeks of the colony. Through the use of this name, some of the early shared history can be recognised. The dual-naming proposal was discussed by Holdfast Bay Council where it was decided by a vote of 7 to 5 to place the name of the former Mayor Brian Nadilo before the Kaurna name.

8 See http://www.tourism.holdfast.sa.gov.au/site/page.cfm?u=589\&c=2794. 
However, because many were ignoring the Kaurna name, it was later decided that the reserve should be referred to as Ngutinilla only when the name needs to be shortened (Messenger, 13 June 2007).

\subsection{New names for previously un-named features}

Other previously un-named features are sometimes being given Kaurna names. In 1996 a previously un-named creek was named Kuranye (rainbow) Creek in reference to the multi-coloured sands nearby (see Amery 1998 Vol. 2: 277). In 2007 an un-named watercourse was named Turraparri (see below). Many local government authorities are turning to the Kaurna language as a source of names for parks, reserves and wetlands. The naming proposal that was developed for the Adelaide City Council in 1996 (see Amery and Williams 2002 for details) included 22 parks then known only by numbers. All of those names have since been adopted.

\subsubsection{Taikurrendi (identifying the correct form)}

On 11 February 2005, a new park was opened in front of the Christies Beach Surf Lifesaving Club (see http://www.onkaparingacity.com/web/binaries?img $=4838 \&$ stypen $=$ html). A Kaurna translation was sought for the introduction section to the Draft Tappa Iri agreement document. One paragraph read:

The Kaurna Tappa Iri Reconciliation Agreement is an outcome of working together for many years on individual projects such as the Living Kaurna Cultural Centre at Warriparinga, foreshore redevelopments at Christies Beach (Tarkarendi), Pt Willunga (Ruwaraung) and Holdfast Bay, management of the Tjilbruke Track and Red Ochre Point (Portartang) and discussion in the Tjilbruke Dreaming Forum. (Kaurna Tappa Iri Reconciliation Agreement 2005-2008, p. 3)

Here we see the use of names of Ngarrindjeri appearance (Ruwaraung and Portartang) ${ }^{9}$ alongside Kaurna Taikurrendi (meaning 'to be mixed; together') misspelt as Tarkarendi (which means 'to name; sing') in this document. This misrepresentation in the Draft Tappa Iri agreement has caused a great deal of confusion and errors within the Kaurna translation which was done in collaboration with Kaurna people (Leonie Brodie and Buster Turner from Tappa Iri and Dennis O'Brien from KWP). I (Amery) was not aware that the park had been named Taikurrendi at that time. Because the erroneous spelling was, in fact, a legitimate Kaurna word, and it was cited in the context of a name without definition, the error could not be identified. This example shows how easily errors might arise when people are not very familiar with the language.

9 These two names are usually spelt Ruwarung or Ru:warung and Potartang or Potarta:ng by Tindale. 


\subsubsection{Turraparri - Baxendale Creek}

In 2005, the Geographical Names Unit (GNU) received a request from Wirra Wirra Winery to name the creek flowing through the property into Daringa Swamp on the outskirts of McLaren Vale. A proposal had been put up to name it Baxendale Creek after one of the early settlers. The GNU consulted the Kaurna Heritage Board, and in June 2007 its Chair, Lynette Crocker advised that the creek should be named Mullawirra Para, no doubt in recognition of the Kaurna ancestor Mullawirraburka. Lynette was probably relying on Tindale who places Mullawirra erroneously near Blewitt Springs, which as Schultz (1999: 99) points out, cannot be right. The GNU then sought advice from KWP. The matter was duly considered at the KWP meeting on 18 July 2007.

The true location of Mullawirra is certainly a long way south of Willunga and McLaren Vale in the foothills near Mount Terrible (see Schultz 1999: 37-39, 99-105). If the intention is to reinforce the roots that these names have in the country (see Williams in Amery and Williams, 2002: 267) then it is probably not a good idea to apply this name as proposed.

Para is certainly an early corruption of pari 'river' and survives in a number of well-known placenames such as the Para River, Little Para River, Munno Para, Parafield, Parafield Gardens and Paralowie. There seems little point in reinforcing an early corruption in a new Kaurna name.

The alternative is to propose a name based on the names within the McLaren Vale area. When the location issue was pointed out, Lynette was quite happy for a local name to be used.

We immediately faced the dilemma of having to pin down the form of the name. The name for McLaren Vale was not recorded by T\&S, the most reliable early Kaurna source. We saw previously that the underlying representation is $/ \mathrm{thV}_{1} \mathrm{RV}_{2} /$ where $\mathrm{V}_{1}$ could be /a/, /aa/, /u/ or /uu/, R could be /r/, /r/ or /rr/ whilst $\mathrm{V}_{2}$ could be /a/, /u/ or /i/. That is, there are no less than 36 possible forms/ pronunciations of this name. After looking at the variants and who recorded them and when, we decided that a back vowel /u/ or /uu/ was most likely in the first syllable and that /a/ was reasonably likely in the second syllable. The word turra 'shade; shadow; likeness' is listed in the T\&S (1840) vocabulary and we know from comparison with Nukunu that its phonemic representation is /thura/. Discussion followed about the locality of the creek and the environment through which it flowed. The consensus was that this was a fitting meaning and a suitable name for the creek. Thus the KWP meeting of 18 July 2007 resolved to name the creek Turraparri (RS Turapari) 'shade river' which was accepted by the GNU and now appears on RAA maps (see https://www.raa.com.au/download. asp $x$ ? secid $=294 \&$ file $=$ documents $\backslash$ townmap_87.pdf). 


\section{Conclusion}

Attempts to make sense of erroneous, conflicting, vague and ambiguous source materials present many challenges. Nonetheless, it is seen as a worthwhile pursuit to reinstate the best possible guess at the original form, pronunciation, meaning, cultural context and location of placenames in southern metropolitan Adelaide and the Fleurieu Peninsula and to ensure that these are legitimate Kaurna forms. The results of this analysis are being posted on Google Earth maps allowing the public ready access to the most accurate and reliable information we are able to assemble.

In future, the Kaurna Placenames website, along with the Kaurna Learner's Guide (Amery and Simpson 2013) and the Kaurna Dictionary (Amery and Morley forthcoming) will be the main vehicles through which the revised Kaurna spellings will be introduced to the general public.

We see this as a work in-progress where we are receptive to new evidence and open to revision. We appeal to the public for additional information about names already posted and extra names which are not yet included in the database.

\section{Acknowledgements}

We acknowledge the work of the South Australian state government Geographical Names Unit, the four southern councils (City of Onkaparinga, City of Marion, City of Holdfast Bay and Yankalilla Council) and Beanstalk Creative and Production, without whose effort and support the Kaurna Placenames website would not have been possible. We also acknowledge the untiring work of Chester Schultz who has taken on detailed and exhaustive research of Kaurna placenames since 2007 under the guidance and direction of Kaurna Warra Pintyanthi whose members volunteer their time to discuss this and other Kaurna language projects. Thanks to Chester Schultz, Gerhard Rüdiger and two anonymous reviewers for detailed comments on a draft of this paper.

\section{References}

Amery, Rob 1998, 'Warrabarna Kaurna! Reclaiming Aboriginal Languages from Written Historical Sources: Kaurna Case Study', (2 volumes), PhD thesis, University of Adelaide.

- 2000a, Warrabarna Kaurna: Reclaiming an Australian Language, Swets \& Zeitlinger, Lisse, The Netherlands. 
- 2000b, 'Reclaiming the Kaurna language', in Footprints in the Sand: Kaurna Life in the Holdfast Bay Area to 1850, Y. Allen (compiler), Holdfast Bay Reconciliation Group, Glenelg: 30-40.

- 2002, 'Weeding out spurious etymologies: Toponyms on the Adelaide Plains', in The Land is a Map: Placenames of Indigenous Origin in Australia, L. Hercus, F. Hodges and J. Simpson (eds), Pandanus Books in association with Pacific Linguistics, Canberra: 165-180.

- 2003, Warra Kaurna: A Resource for Kaurna Language Programs. Kaurna Warra Pintyandi, Adelaide.

Amery, R. and J. Morley, forthcoming, Kaurna Dictionary, Kaurna Warra Pintyanthi, Adelaide.

Amery, R. and A. W. Rigney, with Nelson Varcoe, Chester Schultz and Kaurna Warra Pintyandi 2006, Kaurna Palti Wonga. Kaurna Funeral Protocols. Kaurna Warra Pintyandi, Adelaide.

Amery, R. and L. I. Rigney 2006, 'Recognition of Kaurna cultural heritage in the Adelaide Parklands: A linguist's and Kaurna academic's perspective', in Proceedings of The Adelaide Parklands Symposium: A Balancing Act: PastPresent-Future, University of South Australia, Adelaide, 10 November 2006.

Amery, R. and J. Simpson, for Kaurna Warra Pintyanthi 2013, Kulurdu Marni Ngathaitya! Sounds Good to Me: Kaurna Learner's Guide, Wakefield Press, Kent Town.

Amery, R. and G. Y. Williams 2002, 'Reclaiming through renaming: The reinstatement of Kaurna toponyms in Adelaide and the Adelaide Plains', in The Land is a Map: Placenames of Indigenous Origin in Australia, eds. L. Hercus, F. Hodges and J. Simpson, Pandanus Books in association with Pacific Linguistics, Canberra: 255-276.

Berndt, R. and C. Berndt, with J. Stanton 1993, A World That Was: The Yaraldi of the Murray River and the Lakes, South Australia, Melbourne University Press at the Miegunyah Press, Carlton, Vic.

Cockburn, R. 1990, South Australia. What's in a name? (Rev. ed.), Axiom, Adelaide. Original work published 1908.

Gara, T. 1990, 'The life of Ivaritji ('Princess Amelia') of the Adelaide Tribe', in Aboriginal Adelaide, Special Issue of the Journal of the Anthropological Society of South Australia 28(1): 64-104. 
Gaimard, M. 1833, 'Vocabulaire de la langue des habitans du Golfe SaintVincent', in Voyage de découvertes de L'Astrolabe 1826-1827-1828-1829: Philologie, M.J. Dumont D'Urville, Ministère de la Marine, Paris.

Hercus, L. 2002, 'Is it really a placename?', in The Land is a Map: Placenames of Indigenous Origin in Australia, L. Hercus, L.F. Hodges and J. Simpson (eds), Pandanus Books in association with Pacific Linguistics, Canberra, 63-72.

Hercus, L. and J. Simpson 2002, 'Indigenous placenames: an introduction', in The Land is a Map: Placenames of Indigenous Origin in Australia, L. Hercus, L.F. Hodges and J. Simpson (eds), Pandanus Books in association with Pacific Linguistics, Canberra, 1-23.

Hodges, F. 2007, 'Language planning and placenaming in Australia', Current Issues in Language Planning 8(3): 383-403.

Kaurna Placenames website www.kaurnaplacenames.com a collaboration between City of Onkaparinga, City of Marion, City of Holdfast Bay, District Council of Yankalilla with the Kaurna Heritage Board through the Kaurna Tappa Iri Regional Agreement; Kaurna Warra Pintyandi; Land services Group, SA Department for Transport, Energy and Infrastructure; Linguistics Discipline, University of Adelaide; the Australian Government Department of the Environment and Water Resources; and Beanstalk Creative \& Production. Launched in July 2006.

Koeler, Dr H. 1842, 'Einige Notizen über die Eingebornen an der Ostkuste des St Vincent-Golfs in Süd-Australien 1837 und 1838', in Monatsberichte über die Verhandlungen der Gesellschaft für Erdkunde, Berlin.

Manning, G.H. 1990, Manning's Place Names of South Australia, The Author, Adelaide.

Meyer, H.A.E. 1843, Vocabulary of the language spoken by the Aborigines of the southern and eastern portions of the settled districts of South Australia, James Allen, Adelaide.

Nash, J. 2011, 'Insular Toponymies: Pristine place-naming on Norfolk Island, South Pacific and Dudley Peninsula, Kangaroo Island, South Australia', PhD thesis, University of Adelaide.

Piesse, L. 1840, 'Letter to the Editor' of the Adelaide Guardian dated 18 October 1839, The South Australian Colonist 1(19): 296.

Praite, R. and J.C. Tolley 1970, Place Names of South Australia, Rigby, Adelaide. Robinson, G.A. n.d., Papers held in Mitchell Library, Sydney, A7085(6). 
Schultz, C. 1999, 'Kaurna historical and musical notes', in Kaurna Paltinna, Chester Schultz, Nelson Varcoe and Rob Amery, Kaurna Plains School, Elizabeth: 79-121.

— 2011, 'Ask the right question, then look everywhere: Finding and interpreting the old Aboriginal place-names around Adelaide and Fleurieu Peninsula', Paper presented at the Australian National Placenames Survey Conference, SA Dept of Transport, Energy and Infrastructure, Adelaide, 2 September 2011.

—2012, 'Feet on the Fleurieu, language on the land: Kangaroo Islanders, their Aboriginal women and local Aborigines 1831-7: the story of the guides and interpreters in the first explorations of Fleurieu Peninsula', Unpublished manuscript.

Schultz, C., N. Varcoe and R. Amery 1999, Kaurna Paltinna: A Kaurna Songbook, Kaurna Plains School, Elizabeth.

Simpson, J. and L. Hercus 2004, 'Thura-Yura as a Subgroup', in Australian Languages: Classification and the Comparative Method, Claire Bowern and Harold Koch (eds), John Benjamins Publishing Company, Philadelphia: 179-206.

Stephens, J. 1839, The Land of Promise, Smith, Elder \& Co., London.

Teichelmann, C.G. 1857, Dictionary of the Adelaide dialect, MS 4vo. pp. 99 (with double columns). No. 59, Bleek's Catalogue of Sir George Grey's Library dealing with Australian languages, South African Public Library.

Teichelmann, C.G. and C.W. Schürmann 1840, Outlines of a Grammar, Vocabulary, and Phraseology, of the Aboriginal Language of South Australia, Spoken by the Natives in and for some Distance Around Adelaide, Published by the authors at the native location, Adelaide.

Tindale, N.B. n.d., Kaurna place names card file, Tindale Collection, South Australian Museum, Adelaide.

Troy, J. and M. Walsh 2009, 'Reinstating Aboriginal placenames around Port Jackson and Botany Bay', in Aboriginal Placenames: Naming and Re-Naming the Australian Landscape, Harold Koch and Luise Hercus (eds), Aboriginal History Monograph 19, ANU E Press and Aboriginal History Inc., Canberra.

Williams, W. 1840, 'The language of the natives of South Australia', South Australian Colonist 1(19): 295-296.

Wyatt, W. 1879, 'Some account of the manners and superstitions of the Adelaide and Encounter Bay tribes', in The Native Tribes of South Australia, J.D. Woods (ed.), ES Wigg, Adelaide: 157-181. Original MS with corrections in Barr Smith Library Special Collections, University of Adelaide. 
This text taken from Indigenous and Minority Placenames: Australian and International Perspectives, Edited by Ian D. Clark, Luise Hercus and Laura Kostanski, published 2014 by ANU Press, The Australian National University, Canberra, Australia. 